\title{
Pengaruh Kepemimpinan, Kompensasi, dan Motivasi terhadap Kinerja Karyawan
}

\author{
Abu Sari ${ }^{1)}$, Fakhry Zamzam ${ }^{2)}$, Harun Syamsudin ${ }^{3)}$ \\ 1), 2), 3) Universitas Indo Global Mandiri, Palembang, Indonesia \\ Email:abusari0406@gmail.com ${ }^{1)}$,fakhry@uigm.ac.id ${ }^{2)}$,harun@uigm.ac.id ${ }^{3)}$
}

\begin{abstract}
Abstrak
Penelitian ini membahas tentang kepemimpinan, kompensasi, motivasi, dengan tujuan untuk mengetahui pengaruh kepemimpinan, kompensasi dan motivasi terhadap kinerja karyawan. Dengan menggunakan teknik sensus, sampel penelitian yang digunakan adalah sebanyak 55 orang. Peneltian ini menggunakan metode analisis regresi berganda dan diolah dengan SPSS versi 22. Hasil pengujian membuktikan bahwa: (1) Secara parsial kepemimpinan berpengaruh signifikan terhadap kinerja karyawan, sedangkan kompensasi dan motivasi berpengaruh tidak signifikan terhadap kinerja karyawan; (2) Secara simultan didapatkan hasil bahwa kepemimpinan, kompensasi dan motivasi berpengaruh positif dan signifikan terhadap kinerja karyawan.
\end{abstract}

Kata Kunci: Kepemimpinan, Kompensasi, Motivasi, Kinerja

\begin{abstract}
This study discusses leadership, compensation, motivation, with the aim of knowing the effect of leadership, compensation and motivation on employee performance. By using the census technique, the research sample used was 55 people. This research uses multiple regression analysis method and is processed with SPSS version 22. The test results prove that: (1) Partially leadership has a significant effect on employee performance, while compensation and motivation have no significant effect on employee performance; (2) Simultaneously, the results show that leadership, compensation and motivation have a positive and significant effect on employee performance.
\end{abstract}

Keywords: Leadership, Compensation, Motivation, Performance

\section{Pendahuluan}

Dalam suatu organisasi, sumber daya manusia merupakan sumber daya yang memegang peranan sangat penting dibandingkan sumber daya lainnya. Mengapa dikatakan memegang peranan yang sangat penting dalam organisasi? Hal ini karena sumber daya manusia merupakan faktor yang memberikan kontribusi paling dominan dalam pencapaian tujuan organisasi.

Tujuan organisasi dapat dicapai dengan meningkatkan potensi sumber daya manusia. Semakin tinggi kualitas/potensi sumber daya manusia, semakin tinggi pula kinerja sumber daya manusia tersebut. Begitupun sebaliknya, semakin rendah kualitas/potensi sumber daya manusia, maka semakin rendah pula kinerja yang dimiliki sumber daya manusia tersebut. Dapat dikatakan bahwa sumber daya manusia merupakan asset utama dalam suatu organisasi, karena tanpa adanya sumber daya manusia yang handal yang dapat bekerja secara efektif dan efisien, maka sebaik apapun sumber daya lain yang dimiliki suatu organisasi, maka tujuan organisasi tidak akan dapat tercapai dengan maksimal.

Dimilikinya sumber daya manusia yang berkualitas diharapkan mampu menghasilkan tingkat produktivitas kerja yang optimal sesuai dengan apa yang diharapkan. Agar organisasi dapat berkembang sesuai dengan tujuan perusahaan, banyak faktor yang memengaruhinya, antara lain motivasi yang dimiliki tenaga kerja, kompensasi yang diberikan oleh organisasi kepada tenaga 
kerja, termasuk kepemimpinan dalam organisasi.

Peran pimpinan dalam hal ini sangatlah penting, terutama untuk memberikan arahan dan pembinaan terhadap karyawan, sehingga dapat meningkatkan kinerja pada masa yang akan datang. Pembinaan karyawan diarahkan untuk meningkatkan kualitas sumber daya manusia agar memiliki sikap dan perilaku yang bisa mengabdi dan tanggung jawab serta mempunyai etos kerja sehingga dapat memberikan kinerja optimal. Selain itu, motivasi yang diberikan pimpinan kepada seluruh karyawan juga tidak kalah penting dalam usaha peningkatan kinerja karyawan. Variabel lain yang juga memengaruhi adalah kompensasi, dimana kompensasi dapat memberikan rangsangan kepada karyawan agar lebih bersemangat menjalankan tugas-tugas di perusahaan.

Dari hasil uraian di atas, penulis tertarik untuk mengangkat topik penelitian yang berjudul "Pengaruh Kepemimpinan, Kompensasi dan Motivasi Terhadap Kinerja Karyawan".

Berdasarkan uraian pada latar belakang di atas, penulis merumuskan permasalahan sebagai berikut:

1. Bagaimanakah pengaruh kepemimpinan terhadap kinerja karyawan?

2. Bagaimanakah pengaruh kompensasi terhadap kinerja karyawan?

3. Bagaimanakah pengaruh motivasi terhadap kinerja karyawan?

4. Bagaimanakah pengaruh kepemimpinan, kompensasi dan motivasi secara bersama-sama terhadap kinerja karyawan?

\section{Kajian Pustaka}

\subsection{Teori Kepemimpinan}

Suatu organisasi yang berhasil dalam mencapai tujuannya serta mampu memenuhi tanggung jawab akan sangat tergantung dari pimpinannya (Handayani \& Firmansyah, 2016; Al Rasyid, Roswaty, \& Kurniawan; DP, 2020). Oleh karena itu, organisasi membutuhkan pemimpin yang effektif, yang mempunyai kemampuan memengaruhi perilaku bawahannya (Suyadi, 2016; DP, 2018). Seorang pemimpin akan diakui apabila ia dapat mempunyai pengaruh dan dapat mengarahkan bawahannya kearah pencapaian tujuan organisasi. Menurut Greenberg dan Baron (2008), pemimpin adalah individu dalam suatu kelompok atau organisasi yang memegang pengaruh paling atas/tinggi bagi orang lain. Menurut Lensuffie (2010), pemimpin yang dimaksudkan di dalam leadership diartikan sebagai seseorang yang memimpin organisasi/institusi yang terlibat di dalamnya. Robbin (2006), menyatakan bahwa kepemimpinan merupakan kemampuan untuk memengaruhi kelompok menuju pencapaian sasaran.

Kepemimpinan menurut Siagian (2002), adalah kemampuan seseorang untuk memengaruhi orang lain, dalam hal ini para bawahannya sedemikian rupa sehingga orang lain itu mau melakukan kehendak pemimpin meskipun secara pribadi hal itu mungkin tidak disenangi. Gibson et al (2006) mengatakan bahwa kepemimpinan merupakan suatu usaha menggunakan pengaruh untuk memotivasi individu dalam mencapai beberapa tujuan. Sedangkan Richard \& Eagel dalam Yuki (2009) mendefinisikan kepemimpinan adalah cara mengartikulasikan visi, mewujudkan nilai, dan menciptakan lingkungan guna mencapai sesuatu.

Kepemimpinan berpengaruh langsung terhadap tercapainya tujuan organisasi. Pemimpin dapat mempengaruhi moral, kepuasan kerja, dan tingkat prestasi suatu organisasi. Kemampuan 
seorang pemimpin dalam memberikan pengarahan adalah faktor penting pada sebuah organisasi. Tugas utama dari seorang pemimpin adalah mengambil keputusan.

\subsection{Teori Kompensasi}

Kompensasi merupakan salah satu faktor baik secara langsung maupun tidak langsung memengaruhi tinggi rendahnya motivasi dan kinerja pegawai (Erwinsyah, 2016; Handayani, 2018). Karena itu semestinya pemberian kompensasi perlu mendapat perhatian khusus dari instansi agar kinerja pegawai diharapkan akan terus meningkat (Anwar, 2018; Siregar \& Hamdani, 2018). Tujuan organisasi-organisasi yang melaksanakan merit pay/kompensasi adalah untuk meningkatkan kinerja dari para karyawan (Adipati, 2018; Seto, 2018). Hal ini dikarenakan sistem penghargaan ini memotivasi karyawan untuk meningkatkan kinerjanya. (Usmara, 2003). Kompensasi adalah seluruh extrinsic reward yang diterima oleh karyawan dalam bentuk upah atau gaji, insentif atau bonus dan beberapa tunjangan/benefit. (Fajar, 2010).

Pada dasarnya banyak pengertian mengenai kompensasi, menurut para peneliti antara lain menjelaskan tentang pengertian kompensasi:

a. Hasibuan (2007), "Kompensasi adalah semua pendapatan yang berbentuk uang, barang langsung, atau tidak langsung yang diterima karyawan sebagai imbalan jasa yang diberikan kepada perusahaan."

b. Rivai (2004), 'Kompensasi merupakan sesuatu yang diterima karyawan sebagai pengganti kontribusi jasa mereka pada perusahaan. Pemberian kompensasi merupakan salah satu pelaksanaan fungsi manajemen sumber daya manusia yang berhubungan dengan semua jenis penghargaan individual sebagai pertukaran dalam melakukan tugas keorganisasian."

c. Dessler (2002), "Kompensasi adalah setiap bentuk pembayaran atau imbalan yang diberikan kepada pegawai dan timbul dari pekerjaannya.

Dari uraian di atas, dapat disimpulkan bahwa kompensasi terbagi menjadi dua, yakni kompensasi langsung maupun kompensasi tidak langsung. Adapun kompensasi langsung terdiri dari gaji, uang transport, tunjangan hari raya, uang lembur dan tunjangan langsung lainnya. Sedangkan kompensasi tidak langsung terdiri dari promosi jabatan, asuransi, tunjangan jabatan dan mutasi.

\subsection{Teori Motivasi}

Motivasi adalah suatu proses dimana kebutuhan-kebutuhan mendorong seseorang untuk melakukan serangkaian kegiatan yang mengarah ketercapainya tujuan tertentu (Liana, 2020; Sari, 2020). Jika berhasil berhasil dicapai akan memuaskan atau memenuhi kebutuhankebutuhan tersebut (Munandar, 2004; J, 2020).

Dalam pengertian umum, motivasi dikatakan sebagai kebutuhan yang mendorong perbuatan ke arah suatu tujuan tertentu (Anoraga, 2009). Motivasi kerja merupakan salah satu alat atasan agar bawahan mau bekerja keras dan bekerja cerdas sesuai dengan yang diharapkan. Pengetahuan tentang pola motivasi akan membantu para pimpinan memahami sikap kerja masing-masing bawahan, pimpinan akan memotivasi bawahan dengan cara berbeda-beda sesuai dengan pola masing-masing yang paling menonjol. Bawahan perlu dimotivasi karena ada bawahan yang baru mau bekerja setelah dimotivasi atasannya.

Motivasi yang ditimbulkan dari atasan disebut motivasi ekstrinsik dan motivasi yang timbul dari diri sendiri disebut motivasi intrinsik. Motivasi yang timbul dari diri sendiri biasanya akan 
lebih bertahan lama dibandingkan dengan motivasi yang datang dari luar. Begitu pentingnya teori motivasi diterapkan secara tepat sehingga makin banyak ilmuwan yang menekuni kegiatan pengembangan teori tersebut (Siagian, 2001).

Motivasi mempersoalkan bagaimana cara mendorong gairah kerja bawahan, agar mereka mau bekerja keras dengan memberikan semua kemampuan dan keterampilan untuk mewujudkan tujuan perusahaan Hasibuan (1999) dalam Sutrisno (2009). Salah satu tugas paling sulit yang dihadapi oleh berbagai macam organisasi yaitu tugas memotivasi karyawannya (Winardi, 2004). Motivasi adalah keadaan kejiwaan dan sikap mental manusia yang memberikan energi, mendorong kegiatan atau gerakan dan mengarah atau menyalurkan perilaku ke arah mencapai kebutuhan yang memberi kepuasan atau mengurangi ketidakseimbangan (Bernard Berelson \& Gary A. Stainer) dalam (Sinungan, 2009). Motivasi dapat diartikan sebagai bagian integral dari hubungan/industrial dalam rangka proses pembinaan, pengembangan dan pengarah sumber daya manusia dalam suatu perusahaan. (Sinungan, 2009).

Motivasi merupakan proses psikis yang mendorong orang untuk melakukan sesuatu. Dalam memotivasi bawahannya seorang manajer akan berhadapan dengan dua hal yang memengaruhi orang dalam pekerjaan, yaitu kemauan dan kemampuan. Kemauan dapat diatasi dengan pemberian motivasi, sedangkan kemampuan dapat diatasi dengan mengadakan diklat, dengan demikian dapat dirumuskan bahwa kinerja manusia dipengaruhi oleh fungsi motivasi dan kemampuannya. Beberapa teori tentang motivasi menggambarkan perhatian pada pertanyaan “apa penyebab perilaku terjadi dan berhenti?". Jawabannya terpusat pada: pertama, kebutuhan, keinginan atau dorongan untuk melakukan kegiatan. Kedua, hubungan karyawan dengan faktor-faktor eksternal yang menyebabkan mereka melakukan kegiatan.

Dalam pandangan Fillmore H, Stanford (2000), bahwa pengertian motivasi kerja sebagai berikut: "Motivation as an energizing condition of the organism that serves to direct that organism toward the goal of a certain class", yang artinya motivasi kerja sebagai suatu kondisi yang menggerakkan manusia kearah tujuan tertentu. Sementara itu Hasibuan (2000) mendefinisikan motivasi kerja sebagai berikut: "Motivasi kerja adalah suatu perangsang keinginan dan daya penggerak kemauan bekerja seseorang".

\subsection{Teori Kinerja}

Kinerja merupakan hasil kerja secara kualitas dan kuantitas yang dicapai oleh seorang pegawai dalam melaksanakan tugasnya sesuai dengan tanggung jawab yang diberikan kepadanya (Mangkunegara, 2000; Heryati, 2018; Septiadi, Marnisah, \& Handayani, 2020). Menurut Widodo (2005) kinerja adalah melakukan suatu kegiatan dan menyempurnakannya sesuai dengan tanggung jawabnya dengan hasil seperti yang diharapkan, atau suatu hasil karya yang dapat dicapai oleh seseorang atau sekelompok orang dalam suatu organisasi sesuai dengan wewenang dan tanggung jawab masing-masing dalam rangka mencapai tujuan organisasi bersangkutan secara legal, tidak melanggar hukum dan sesuai dengan moral dan etika. Suntoro (dalam Tika, 2006) menyatakan bahwa kinerja adalah hasil kerja yang dapat dicapai oleh seseorang atau sekelompok orang dalam suatu organisasi untuk mencapai tujuan organisasi dalam periode waktu tertentu. Robbins (2003), kinerja merupakan ukuran dari sebuah hasil.

Byars \& Rue (2000) mendefinisikan kinerja sebagai tingkat pencapaian tugas dari pekerjaan karyawan. Kinerja mencerminkan keberhasilan seseorang dalam melaksanakan pekerjaan. Menurut Wirawan (2009), kinerja adalah keluaran yang dihasilkan oleh fungsi-fungsi atau indikator-indikator suatu pekerjaan atau suatu profesi dalam waktu tertentu. Sedangkan menurut Payaman Simanjuntak (2005), kinerja adalah tingkat pencapaian hasil atas 
pelaksanaan tugas tertentu.Kinerja perusahaan adalah tingkat pencapaian hasil dalam rangka mewujudkan tujuan perusahaan. Menurut Gibson et al. (2000), job performance merupakan hasil dari pekerjaan yang terkait dengan tujuan organisasi seperti: kualitas, efisiensi dan kriteria keefektifan lainnya.

Kinerja merupakan kontribusi yang diberikan anggota organisasi terhadap pencapaian tujuan organisasi (Amha \& Brhane, 2020; Bari \& Al-din, 2020; Triani, Halin, \& Wadud, 2020). Irawan (2002) menyatakan bahwa kinerja (performance) adalah hasil kerja yang bersifat konkret, dapat diamati, dan dapat diukur. Jika kita mengenal tiga macam tujuan, yaitu: tujuan organisasi, tujuan unit, dan tujuan pegawai, maka kita juga mengenal tiga macam kinerja, yaitu: kinerja perusahaan, kinerja unit dan kinerja pegawai. (Dessler (2000), berpendapat bahwa kinerja karyawan adalah prestasi aktual karyawan dibandingkan dengan prestasi yang diharapkan dari karyawan. Prestasi yang diharapkan adalah prestasi standar yang disusun sebagai acuan sehingga dapat melihat kinerja karyawan sesuai dengan posisinya dibandingkan dengan standar yang dibuat. Selain itu dapat juga dilihat kinerja dari karyawan tersebut terhadap karyawan lainnya. Menurut pendapat Ilyas (2005) mengatakan bahwa pengertian kinerja adalah penampilan, hasil karya personil, baik kualitas maupun kuantitas penampilan individu maupun kelompok kerja personil, penampilan hasil karya tidak terbatas kepada personil yang memangku jabatan fungsional maupun struktural tetapi juga kepada keseluruhan jajaran personil di dalam organisasi.

Berdasarkan beberapa pendapat tentang kinerja dan prestasi kerja, dapat disimpulkan bahwa kinerja adalah cerminan hasil yang dicapai oleh seseorang atau sekelompok orang dalam melaksanakan tugas dan tanggung jawab menurut ukuran atau standar yang berlaku pada masing-masing organisasi.

\subsection{Penelitian Terdahulu}

Penelitian yang dilakukan oleh Maria Gratia (2016), mengenai pengaruh kepemimpinan, kompetensi, motivasi dan kompensasi terhadap kinerja pegawai menyatakan bahwa kepemimpinan, kompetensi, motivasi dan kompensasi secara simultan berpengaruh terhadap kinerja, tetapi secara parsial kepemimpinan dan motivasi berpengaruh secara positif terhadap kinerja sedangkan kompetensi dan kompensasi berpengaruh negative tidak signifikan terhadap kinerja.

Anggara Nasution (2013), dalam penelitiannya mengemukakan bahwa secara simultan maupun parsial kepemimpinan, remunerasi dan motivasi mempunyai pengaruh yang positif dan signifikan terhadap kinerja. Sama halnya dengan penelitian Wahyu Bagaskara (2017), dengan menggunakan analisis regresi linier sederhana dan berganda, mengemukakan bahwa kompensasi, motivasi kerja dan kepemimpinan berpengaruh positif dan signifikan terhadap kinerja karyawan.

\subsection{Kerangka Pemikiran}

Variabel yang dianalisis adalah variabel independen yaitu kepemimpinan, kompensasi dan motivasi (variabel X1, X2, dan X3) sedangkan variabel dependen adalah kinerja (variabel Y). Pengujian yang dilakukan adalah untuk mengetahui pengaruh variabel independen X1, X2, dan X3 terhadap Y baik secara parsial maupun secara simultan. 
Gambar 1. Diagram Jalur Pengaruh Kepemimpinan, Kompensasi, dan Motivasi terhadap Kinerja

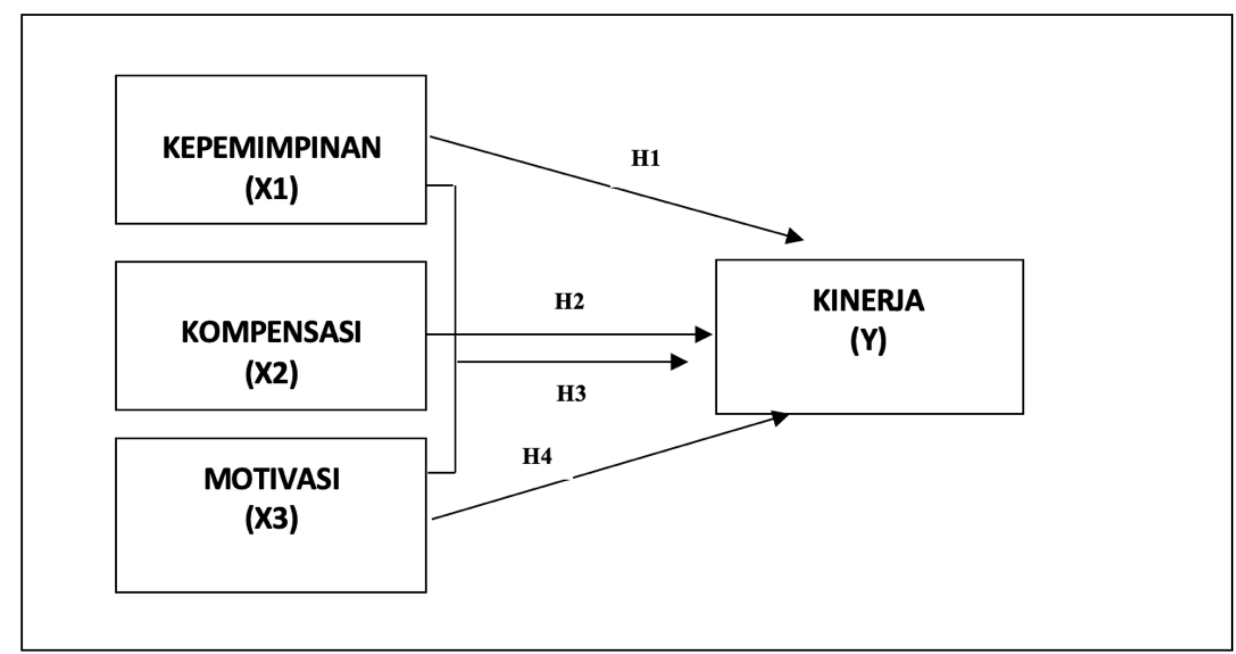

\section{Metodologi Penelitian}

\subsection{Metode Penelitian}

Metode penelitian yang penulis gunakan pada penelitian ini adalah penelitian survai dengan jenis penelitian penjelasan (eksplanatori) yang bertujuan menganalisis hubungan-hubungan antara satu variabel dengan variabel lain atau bagaimana suatu variabel memengaruhi variabel lain. Penelitian penjelasan yang dimaksud untuk menyoroti hubungan antar variabel dan menguji hipotesis yang telah dirumuskan (Masri Singarimbun dan Sofyan Effendi, 1995).

\subsubsection{Teknik Pengumpulan Data}

Metode yang digunakan dalam pengumpulan data adalah:

a. Kuesioner

b. Dilakukan dengan menyebar daftar pertanyaan kepada pelanggan yang menjadi sampel dari populasi penelitian, metode ini untuk menggali data primer dan memperoleh informasi secara tertulis dari responden sebagai objek penelitian.

c. Interview atau wawancara

Yaitu suatu cara untuk memperoleh data dengan jalan mengadakan tanya jawab secara langsung dengan pihak-pihak yang bersangkutan dengan bidang yang diteliti dengan harapan memperoleh informasi yang dibutuhkan. Informasi yang diperoleh memperjelas atau mendukung jawaban yang disampaikan melalui kuesioner.

\section{d. Dokumentasi}

Yaitu suatu cara memperoleh informasi melalui dokumen dan literatur ataupun jurnaljurnal yang relevan dengan data penelitian.

\subsubsection{Populasi dan Sampel Penelitian}

Teknik pengambilan sampel dalam penelitian ini adalah menggunakan cara sensus. Sensus menurut J. Supranto (2008) adalah cara pengumpulan data apabila seluruh elemen populasi diselidiki satu persatu. Teknik ini digunakan karena jumlah populasi dianggap tidak terlalu 
banyak dan mudah dalam mengumpulkan datanya, sehingga peneliti dapat memperoleh informasi yang lebih lengkap tentang kondisi yang sebenarnya. Sampel dalam penelitian ini adalah seluruh populasi yaitu 64 orang karyawan. Namun dari 64 kuesioner yang disebar hanya sebanyak 55 kuesioner yang kembali, maka sampel penelitian yang diambil adalah sebanyak jumlah kuesioner yang kembali, yaitu 55 karyawan.

\subsubsection{Variabel Penelitian dan Definisi Operasional}

Variabel dalam penelitian ini adalah variabel dependen. Variabel ini merupakan variabel dipengaruhi oleh variabel lain. Adapun variabel dependen yang digunakan dalam penelitian ini yaitu: Kinerja karyawan. Kinerja adalah tingkat pencapaian dari tugas yang dilakukan oleh pegawai. Penilaian kinerja karyawan dilaksanakan berdasarkan kepemimpinan, jaringan sosial, komunikasi, pengendalian emosi, agen perubahan, integritas empati, pengelolaan administrasi, kreativitas dan kemandirian. Faktor kinerja kepemimpinan sebagaimana dimaksud antara lain meliputi kemampuan untuk mempengaruhi, memotivasi, dan mengarahkan. Faktor kinerja jaringan sosial sebagaimana dimaksud meliputi kemampuan membangun, memelihara, dan melaksanakan kerjasama serta hubungan baik dengan pegawai dan masyarakat. Faktor kinerja komunikasi sebagaimana dimaksud antara lain meliputi kemampuan menerima ide, merumuskan, mengutarakan, dan menerima ide/pendapat baik secara verbal maupun nonverbal, dengan jelas sesama pegawai dan masyarakat.

Variabel selanjutnya adalah variabel independen yang merupakan variabel bebas atau tidak terikat oleh variabel lain. Variabel independen dalam penelitian ini adalah sebagai berikut:

a. Variabel $\left(\mathrm{X}_{1}\right)$ Kepemimpinan

Kepemimpinan merupakan suatu usaha menggunakan pengaruh untuk memotivasi individu dalam mencapai beberapa tujuan (Gibson et al, 2006). Menurut House (dalam Robbins, 2001), kepemimpinan berdasarkan perilaku dibagi menjadi 4, yaitu:

1. Directive, memberikan petunjuk apa yang harus dikerjakan, menetapkan jadwal kerja dan menetapkan standar kerja.

2. Supportive, memperlakukan bawahan secara sama, bersahabat dan mudah ditemui, serta peduli dengan keinginan bawahan.

3. Achievement Oriented, memberikan tantangan dalam mencapai tujuan, menetapkan standar kerja yang tinggi dan menekankan peningkatan kinerja secara berkala.

4. Participative, selalu melibatkan karyawan dalam mengambil keputusan, berkonsultasi, dan meminta saran kepada bawahan dalam membuat keputusan.

Indikator pengukuran variabel kepemimpinan dalam penelitian ini adalah: hasil kerja, pendekatan diri (terutama kepada bawahan), prestasi kerja, dan melibatkan bawahan dalam pengambilan keputusan.

\section{b. Variabel $\left(\mathrm{X}_{2}\right)$ Kompensasi}

Kompensasi adalah seluruh bentuk imbalan baik berupa finansial maupun non finansial seperti upah, gaji, tunjangan, bonus, uang makan, uang lembur jaminan kesehatan dan insentif yang diberikan kepada karyawan sebagai imbalan atau balas jasa dalam melakukan tugas keorganisasian. Adapun indikator pengukuran variabel kompensasi dalam penelitian ini adalah: 
1. Upah/gaji tetap yang diterima

2. Pendapatan finansial lainnya (bonus,uang lembur,hadiah)

3. Pemberian jaminan kesehatan

4. Pemberian penghargaan khusus.

c. Variabel $\left(\mathrm{X}_{3}\right)$ Motivasi

Motivasi adalah suatu kekuatan dan daya dorong yang dimiliki seseorang untuk menimbulkan semangat dan antusias dalam melaksanakan pekerjaan sehingga mencapai tujuan. Adapun indikatornya adalah:

1. Kebutuhan untuk berprestasi, yaitu upaya untuk berprestasi baik dan mengembangkan diri.

2. Kebutuhan untuk berafiliasi, yaitu semangat untuk berinteraksi dengan lingkungannya, dan semangat untuk dapat bekerjasama.

3. Kebutuhan untuk berkuasa, yaitu semangat untuk menduduki jabatan tertinggi dan semangat untuk menguasai orang.

\subsection{Teknik Analisis Data}

Metode analisis data dalam penelitian ini menggunakan teknik analisis regresi berganda (multiple regression analysis) dengan teknik pengolahan data menggunakan SPSS versi 22.

\subsection{Rancangan Uji Hipotesis}

Dalam penelitian ini ada 4 hipotesis yang diajukan. Menurut Imam Ghozali (2005), bahwa dasar pengambilan keputusan yaitu sebagai berikut:

a. Dengan membandingkan nilai $t$ hitungnya dengan $t$ tabel. Apabila $t$ tabel $>t$ hitung, maka Ho diterima dan $\mathrm{H} 1$ ditolak. Apabila $\mathrm{t}$ tabel $<\mathrm{t}$ hitung, maka Ho ditolak dan $\mathrm{H} 1$ diterima. Dengan tingkat signifikansi 5\%.

b. Dengan menggunakan angka probabilitas signifikansi. Apabila angka probabilitas signifikasi $>0,05$, maka Ho diterima dan H1 ditolak. Apabila angka probabilitas signifikansi $<0,05$, maka Ho ditolak dan $\mathrm{H} 1$ diterima.

Tabel 1. Rencana Uji Hipotesis

\begin{tabular}{|l|l|l|l|}
\hline No & Hipotesis & \multicolumn{1}{|c|}{ Pernyataan Hipotesis } & Penerimaan Hipotesis \\
\hline 1. & $\mathrm{Ho}_{1}$ & $\begin{array}{l}\text { Kepemimpinan tidak berpengaruh secara } \\
\text { parsial terhadap kinerja karyawan }\end{array}$ & Nilai $t$-stat $<t$-tabel \\
\cline { 2 - 4 } & $\mathrm{Ha}_{1}$ & $\begin{array}{l}\text { Kepemimpinan berpengaruh secara parsial } \\
\text { terhadap kinerja karyawan }\end{array}$ & $\begin{array}{l}\text { Nilai } t \text {-stat }>t \text {-tabel } \\
\text { Sig }(\mathrm{P})<0,05\end{array}$ \\
\hline 2. & $\mathrm{Ho}_{2}$ & $\begin{array}{l}\text { Kompensasi tidak berpengaruh secara parsial } \\
\text { terhadap kinerja karyawan }\end{array}$ & $\begin{array}{l}\text { Nilai } t \text {-stat }<t \text {-tabel } \\
\text { Sig }(\mathrm{P})>0,05\end{array}$ \\
\hline
\end{tabular}


(Vol. 1, No. 2, Desember 2020

\begin{tabular}{|c|c|c|c|}
\hline & $\mathrm{Ha}_{2}$ & $\begin{array}{l}\text { Kompensasi berpengaruh secara parsial } \\
\text { terhadap kinerja karyawan }\end{array}$ & $\begin{array}{l}\text { Nilai } t \text {-stat }>t \text {-tabel } \\
\text { Sig }(\mathrm{P})<0,05\end{array}$ \\
\hline \multirow[t]{2}{*}{3.} & $\mathrm{Ho}_{3}$ & $\begin{array}{l}\text { Motivasi tidak berpengaruh secara parsial } \\
\text { terhadap kinerja karyawan }\end{array}$ & $\begin{array}{l}\text { Nilai } t \text {-stat }<t \text {-tabel } \\
\text { Sig }(\mathrm{P})>0,05\end{array}$ \\
\hline & $\mathrm{Ha}_{3}$ & $\begin{array}{l}\text { Motivasi berpengaruh secara parsial terhadap } \\
\text { kinerja karyawan }\end{array}$ & $\begin{array}{l}\text { Nilai } t \text {-stat }>t \text {-tabel } \\
\text { Sig }(\mathrm{P})<0,05\end{array}$ \\
\hline \multirow[t]{2}{*}{4.} & $\mathrm{Ho}_{4}$ & $\begin{array}{l}\text { Kepemimpinan, Kompensasi dan Motivasi } \\
\text { tidak berpengaruh secara parsial terhadap } \\
\text { kinerja karyawan }\end{array}$ & $\begin{array}{l}\text { Nilai } F \text {-stat }<t \text {-tabel } \\
\text { Sig }(\mathrm{P})>0,05\end{array}$ \\
\hline & $\mathrm{Ha}_{4}$ & $\begin{array}{l}\text { Kepemimpinan, Kompensasi dan Motivasi } \\
\text { berpengaruh secara parsial terhadap kinerja } \\
\text { karyawan }\end{array}$ & $\begin{array}{l}\text { Nilai } t \text {-stat }>t \text {-tabel } \\
\text { Sig }(\mathrm{P})<0,05\end{array}$ \\
\hline
\end{tabular}

\section{Analisis dan Pembahasan}

\subsection{Hasil Analisis}

\subsubsection{Hasil Uji Validitas dan Reliabilitas}

Pada penelitian ini akan menguji validitas instrumen dengan 55 orang sebagai responden. Uji validitas dapat dilakukan dengan cara mengkorelasikan setiap butir dengan skor total yang merupakan tiap skor pertanyaan yang dijawab oleh responden dengan menggunakan rumus teknik korelasi total produk moment yang ada dalam SPSS.

Jika koefisien korelasi positif dan atau lebih besar dari nilai $r$ tabel, maka item yang bersangkutan itu valid, jika lebih kecil dan atau negatif maka item tersebut dikeluarkan dari kuesioner. Angka kritis korelasi tabel (r-tabel) yang diperoleh adalah 0,2656. Angka ini diperoleh dari n-2 atau 55-2 = 53 dalam tabel PPM. Dengan demikian apabila ada koefisien korelasi butir instrument berada dibawah 0, 2656 dinyatakan tidak valid.

Untuk mencari reliabilitas instrument dapat dilakukan setelah kuisioner ditabulasi, maka dilakukan uji reliabilitas untuk mengetahui tingkat kepercayaan atas kesungguhan jawaban responden dapat dipercaya. Jika kedua aspek tersebut yaitu aspek stabilitas dan aspek akurasi digabungkan maka dapat disimpulkan bahwa alat ukur mantap dan dapat mengukur secara cermat dan tepat, sehingga kesalahan yang terjadi yaitu kesalahan pengukuran yang random sifatnya dapat ditaksir. Berikut adalah hasil pengujian validitas dan reliabilitas terhadap alat ukur variabel independen seperti pada tabel berikut ( $\mathrm{r}$ tabel $=0.2656, \mathrm{t}$ tabel $=2,0057$ ).

Tabel 2. Hasil Uji Validitas dan Reliabilitas Variabel

\begin{tabular}{|c|c|c|c|c|c|}
\hline Variabel & Alpha & Keterangan & Item & CITC & Keterangan \\
\hline X1 & 0,947 & Reliabel & $\mathrm{x} 1.1$ & .933 & Valid \\
\cline { 3 - 6 } & & & $\mathrm{x} 1.2$ & .902 & Valid \\
\cline { 3 - 5 } & & &
\end{tabular}




\begin{tabular}{|c|c|c|c|c|c|}
\hline & & & $\mathrm{x} 1.3$ & .932 & Valid \\
\hline & & & $\mathrm{x} 1.4$ & .688 & Valid \\
\hline & & & $\mathrm{x} 1.5$ & .909 & Valid \\
\hline & & & x1.6 & .707 & Valid \\
\hline \multirow[t]{5}{*}{$\mathrm{X} 2$} & \multirow[t]{5}{*}{0,869} & \multirow[t]{5}{*}{ Reliabel } & $\mathrm{x} 2.1$ & .822 & Valid \\
\hline & & & $\mathrm{x} 2.2$ & .865 & Valid \\
\hline & & & $\mathrm{x} 2.3$ & .586 & Valid \\
\hline & & & $\mathrm{x} 2.4$ & .557 & Valid \\
\hline & & & $\mathrm{x} 2.5$ & .728 & Valid \\
\hline \multirow[t]{6}{*}{ X3 } & \multirow[t]{6}{*}{0,914} & \multirow[t]{6}{*}{ Reliabel } & x 3.1 & .718 & Valid \\
\hline & & & $\mathrm{x} 3.2$ & .738 & Valid \\
\hline & & & $\mathrm{x} 3.3$ & .732 & Valid \\
\hline & & & x 3.4 & .703 & Valid \\
\hline & & & $\mathrm{x} 3.5$ & .897 & Valid \\
\hline & & & x3.6 & .780 & Valid \\
\hline \multirow[t]{6}{*}{$\mathrm{Y}$} & \multirow[t]{6}{*}{0,907} & \multirow[t]{6}{*}{ Reliabel } & y01 & .730 & Valid \\
\hline & & & y02 & .808 & Valid \\
\hline & & & y03 & .712 & Valid \\
\hline & & & y04 & .625 & Valid \\
\hline & & & y05 & .803 & Valid \\
\hline & & & y06 & .823 & Valid \\
\hline
\end{tabular}

*(CITC $=$ Corrected Item Total Corelation atau $\mathrm{r}$ hitung $)$

\subsubsection{Hasil Uji Asumsi Klasik}

\subsubsection{Uji Multikolinieritas}

Pengujian Multikolineritas bertujuan untuk menguji apakah pada model regresi ditemukan adanya korelasi antar variabel independen. Model regresi yang baik seharusnya tidak terjadi korelasi antar variabel independen. Untuk mendeteksi adanya multikolinearitas, maka dapat 
dilihat dengan besaran nilai VIF (Variance Inflation Factor) dan Tolerance. Persamaan regresi yang bebas multikolinieritas adalah: mempunyai nilai VIF tidak melebihi angka 10 dan mempunyai angka tolerance mendekati 1 . Untuk hasil pengujian multikolinearitas, dapat dilihat dari tabel 3 berikut:

Tabel 3. Uji Multikolinearitas

\begin{tabular}{|c|l|c|c|}
\hline \multirow{2}{*}{ No } & \multicolumn{1}{|c|}{ Variabel } & \multicolumn{2}{c|}{ Collinearity statistics } \\
\cline { 3 - 4 } & & Tolerance & VIF \\
\hline 1 & Kepemimpinan (X1) & .852 & 1.174 \\
\hline 2 & Kompensasi (X2) & .973 & 1.028 \\
\hline 3 & Motivasi (X3) & .874 & 1.144 \\
\hline
\end{tabular}

Pada tabel 3 terlihat nilai tolerance berada mendekati angka 1 dan nilai VIF untuk ketiga variabel independen tidak melebihi angka 10, maka tidak terdapat masalah multikolinearitas.

\subsubsection{Uji Heteroskedastisitas}

Uji Heteroskedastisitas bertujuan untuk menguji apakah dalam model regresi terjadi ketidaksamaan varians dari residual satu pengamatan ke pengamatan, atau yang lain. Untuk melihat ada tidaknya masalah heteroskedastisitas dapat dideteksi dengan ada tidaknya pola tertentu pada grafik scater plot, apabila ada pola tertentu, seperti titik-titik yang membentuk pola teratur (bergelombang, melebar kemudian menyempit) maka telah terjadi heteroskedastisitas. Sedangkan jika tidak terdapat pola yang jelas, serta titik-titik menyebar diatas dan dibawah angka 0 dan sumbu Y, maka tidak terjadi heteroskedastisitas. Hasil dari pengujuan heteroskedastisitas dapat dilihat pada gambar 2 .

Gambar 2. Uji Heteroskedastisitas

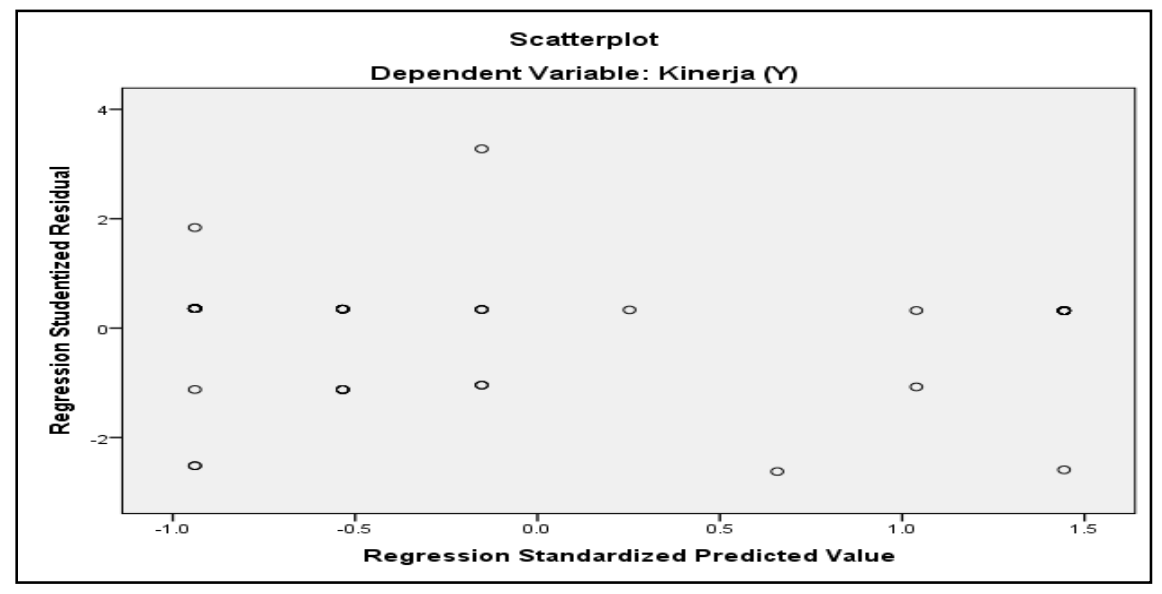

\subsubsection{Uji Normalitas}

Uji normalitas untuk menguji apakah dalam sebuah model regresi, variabel dependent, variabel independen, atau keduanya mempunyai distribusi normal atau tidak.Untuk mendeteksi model regresi normal atau tidak, dapat dilihat dari Normal P-P Plot. Jika data menyebar disekitar garis diagonal dan mengikuti arah garis diagonal, maka model regresi memenuhi asumsi normalitas. 
Jika tidak, atau data menyebar jauh dari garis diagonal, maka model regresi tidak memenuhi asumsi normalitas.

Hasil uji normalitas dapat dilihat dari gambar 3 di bawah. Dari gambar tersebut, terlihat titiktitik menyebar disekitar garis diagonal serta penyebarannya mengikuti arah garis diagonal. Maka model regresi layak dipakai untuk prediksi variabel kinerja karyawan berdasarkan masukan dari variabel kepemimpinan, kompensasi dan motivasi.

Gambar 3. Uji Normalitas

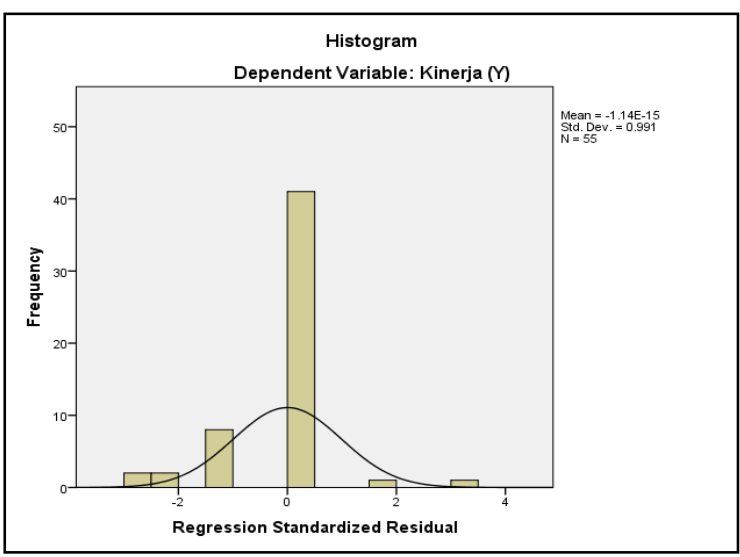

\subsubsection{Hasil Uji Regresi Linier Berganda}

\subsubsection{Uji Statistik t (Uji hipotesis secara parsial)}

Pada analisis regresi ini digunakan metode backward, dimana pada metode ini pada pengujian awalnya, semua variabel independen diikut sertakan dalam pengujian kemudian baru disingkirkan atau diremove satu persatu apabila tidak memenuhi nilai signifikansi t dibawah 0,05 . Pada tabel output yang dihasilkan akan diperlihatkan proses atau tahapan saat variabel tersebut disingkirkan, setiap baris akan dilengkapi dengan angka yang menunjukkan tahapan atau proses yang dilakukan. Pada pembahasan mengenai analisis ini, hanya akan dibahas pada proses terakhir di setiap tabel, hal ini dimaksudkan karena pada setiap baris terakhir adalah hasil pengujian terakhir yang merupakan variabel yang memiliki nilai signifikasi t dibawah 0,05.

Proses hasil uji hipotesis secara parsial atau uji t dalam penelitian ini dapat dilihat pada tabel 4 berikut:

Tabel 4. Coefficients

\begin{tabular}{|c|c|c|c|c|c|c|c|}
\hline \multirow[b]{2}{*}{ Model } & \multicolumn{2}{|c|}{$\begin{array}{c}\text { Unstandardized } \\
\text { Coefficients }\end{array}$} & \multirow{2}{*}{\begin{tabular}{|c}
$\begin{array}{c}\text { Standardized } \\
\text { Coefficients }\end{array}$ \\
Beta
\end{tabular}} & \multirow[b]{2}{*}{$\mathrm{T}$} & \multirow[b]{2}{*}{ Sig. } & \multicolumn{2}{|c|}{$\begin{array}{l}\text { Collinearity } \\
\text { Statistics }\end{array}$} \\
\hline & B & Std. Error & & & & Tolerance & VIF \\
\hline (Constant) & .069 & .291 & & .237 & .813 & & \\
\hline $\begin{array}{l}\text { Kepemimpinan } \\
\text { (X1) }\end{array}$ & 1.009 & .042 & .968 & 24.296 & .000 & .852 & 1.174 \\
\hline Kompensasi (X2) & -.031 & .034 & -.034 & -.904 & .370 & .973 & 1.028 \\
\hline
\end{tabular}




\begin{tabular}{|l|l|l|l|l|l|l|l|}
\hline Motivasi (X3) & -.004 & .033 & -.005 & -.119 & .905 & .874 & 1.144 \\
\hline
\end{tabular}

a. Dependent Variable: Kinerja (Y)

Dari tabel coefficient diatas terlihat persamaan regresi yang terbentuk adalah:

$\mathrm{Y}=0.069+1,009 \mathrm{X} 1-0,031 \mathrm{X} 2-0,004 \mathrm{X} 3$

$\begin{array}{lll}\text { Dimana: } & \mathrm{Y} & : \text { Kinerja karyawan } \\ & \mathrm{X} 1 & : \text { Kepemimpinan } \\ \mathrm{X} 2 & : \text { Kompensasi } \\ \mathrm{X} 3 & : \text { Motivasi }\end{array}$

\subsubsection{Uji Statistik F (Uji hipotesis secara simultan)}

Uji statistik F digunakan untuk mengetahui pengaruh variabel independen secara simultan atau bersama - sama terhadap variabel dependen. Jika nilai signifikansi $<0,05$ atau $5 \%$ maka dapat diartikan bahwa secara bersama-sama atau simultan, variabel independen berpengaruh secara signifikan terhadap variabel dependen. Namun jika nilai signifikansi $>0,05$ atau 5\% maka dapat diartikan bahwa secara simultan atau bersama-sama variabel independen tidak berpengaruh secara signifikan terhadap variabel dependen. Hasil uji statistik F dalam penelitian ini dapat dilihat pada tabel 5 berikut:

Tabel 5. Uji Statistik F

\begin{tabular}{|l|l|r|r|r|c|c|}
\hline \multicolumn{2}{|l|}{ Model } & Sum of Squares & Df & Mean Square & F & Sig. \\
\hline 1 & Regression & 9.610 & 3 & 3.203 & 229.442 & $.000^{\mathrm{b}}$ \\
\cline { 2 - 7 } & Residual & .712 & 51 & .014 & & \\
\cline { 2 - 7 } & Total & 10.322 & 54 & & & \\
\hline
\end{tabular}

a. Dependent Variable: Kinerja (Y)

b. Predictors: (Constant), Motivasi (X3), Kompensasi (X2), Kepemimpinan (X1)

Dari tabel anova diatas terlihat bahwa pada model regresi, nilai signifikansi $\mathrm{F}$ dibawah 0.05 artinya secara keseluruhan variabel independen memberikan pengaruh secara signifikan terhadap variabel dependen.

\subsubsection{Uji Koefisien Determinasi $\left(\mathrm{R}^{2}\right)$}

Koefisien Determinasi $\mathrm{R}^{2}$ dalam regresi linier berganda digunakan untuk mengukur dan menguji kemampuan model dalam menjelaskan variabel dependen. Dalam penelitian ini, koefisien determinasi digunakan untuk mengetahui seberapa besar hubungan antara kepemimpinan, kompensasi dan motivasi terhadap kinerja karyawan. Hasil uji koefisien determinasi pada penelitian ini dapat dilihat pada tabel 6 di bawah.

Dari tabel di atas terlihat bahwa nilai korelasi antara variabel independen dengan variabel dependen sebesar 0.964 artinya sangat kuat. Sedangkan nilai $\mathrm{r}^{2}$ (Koefisien determinasi) sebesar 
0.930 artinya variabel independen dapat menjelaskan variabel dependen sebesar 93\% sedangkan sisanya $(100 \%-93 \%=7 \%)$ dijelaskan oleh faktor lain.

Tabel 6. Hasil Uji Koefisien Determinasi $\left(\mathrm{R}^{2}\right)$

\begin{tabular}{|l|r|r|r|r|}
\hline \multicolumn{1}{|l|}{ Model } & \multicolumn{1}{|c|}{$\mathrm{R}$} & \multicolumn{1}{c|}{ R Square } & Adjusted R Square & \multicolumn{2}{c|}{$\begin{array}{c}\text { Std. Error of the } \\
\text { Estimate }\end{array}$} \\
\hline 1 & $.965^{\mathrm{a}}$ & .931 & .927 & .11816 \\
\hline 2 & $.965^{\mathrm{b}}$ & .931 & .928 & .11703 \\
\hline 3 & $.964^{\mathrm{c}}$ & .930 & .929 & .11686 \\
\hline
\end{tabular}

a. Predictors: (Constant), Motivasi (X3), Kompensasi (X2), Kepemimpinan (X1)

b. Predictors: (Constant), Kompensasi (X2), Kepemimpinan (X1)

c. Predictors: (Constant), Kepemimpinan (X1)

d. Dependent Variable: Kinerja (Y)

\subsection{Pembahasan}

\subsubsection{Analisis Pengaruh Kepemimpinan terhadap Kinerja Karyawan}

Seorang Pemimpin dapat memengaruhi moral, kepuasan kerja, dan tingkat prestasi suatu organisasi. Kemampuan seorang pemimpin dalam memberikan pengarahan adalah faktor penting pada sebuah organisasi. Tugas utama dari seorang pemimpin adalah mengambil keputusan. Menurut Richard \& Eagel dalam Yuki (2009) mendefinisikan kepemimpinan adalah cara mengartikulasikan visi, mewujudkan nilai, dan menciptakan lingkungan guna mencapai sesuatu. Kepemimpinan berpengaruh langsung terhadap tercapainya tujuan organisasi.

Berdasarkan hipotesis peneliti:

$\mathrm{Ho}_{1}$ : Kepemimpinan tidak berpengaruh secara parsial terhadap kinerja karyawan

$\mathrm{Ha}_{1}$ : Kepemimpinan berpengaruh secara parsial terhadap kinerja karyawan

Dari hasil penelitian, diperoleh $t$ hitung sebesar 24,296, sedangkan $t$ tabel sebesar : 2,0057, sehingga dari hasil yang didapatkan $t$ hitung $>t$ tabel, dengan tingkat signifikansi sebesar 0,00 yang berada dibawah 0,05 berarti hipotesis Ha diterima, bahwa variabel kepemimpinan berpengaruh secara parsial terhadap kinerja karyawan dan signifikan.

\subsubsection{Analisis Pengaruh Kompensasi terhadap Kinerja Karyawan}

Kompensasi berkaitan dengan kesejahteraan pegawai. Dengan adanya kompensasi yang diberikan, akan mendorong pegawai untuk meningkatkan kinerja nya. Hal ini dikarenakan sistem penghargaan ini memotivasi karyawan untuk meningkatkan kinerjanya. (Usmara, 2003: 217). Kompensasi adalah seluruh extrinsic reward yang diterima oleh karyawan dalam bentuk upah atau gaji, insentif atau bonus dan beberapa tunjangan/benefit. (Fajar, 2010: 154).

Berdasarkan hipotesis peneliti: 
$\mathrm{Ho}_{2}$ : Kompensasi tidak berpengaruh secara parsial terhadap kinerja karyawan

$\mathrm{Ha}_{2}$ : Kompensasi berpengaruh secara parsial terhadap kinerja karyawan

Dari hasil penelitian, diperoleh $\mathrm{t}$ hitung sebesar -0,904, sedangkan $\mathrm{t}$ tabel sebesar 2,0057, sehingga dari hasil yang didapatkan $t$ hitung $<\mathrm{t}$ tabel, dengan tingkat signifikansi sebesar 0,370 yang berada diatas 0,05 berarti hipotesis Ho diterima, bahwa variabel kompensasi tidak berpengaruh secara parsial terhadap kinerja karyawan. Hal ini sejalan dengan penelitian yang telah dilakukan oleh Marnesya Afifah yang menyatakan bahwa kompensasi secara parsial tidak berpengaruh terhadap kinerja.

\subsubsection{Analisis Pengaruh Motivasi terhadap Kinerja Karyawan}

Motivasi merupakan suatu penggerak dalam hati seseorang untuk melakukan atau mencapai suatu tujuan. Motivasi dapat ditumbuhkan baik dari dalam diri maupun dari luar manusia itu sendiri. Motivasi sangat penting, karena dengan motivasi diharapkan setiap individu mau bekerja keras dan antusias untuk mencapai kinerja yang baik.

Berdasarkan hipotesis peneliti:

$\mathrm{Ho}_{3}$ : Motivasi tidak berpengaruh secara parsial terhadap kinerja karyawan

$\mathrm{Ha}_{3}$ : Motivasi berpengaruh secara parsial terhadap kinerja karyawan

Dari hasil penelitian, diperoleh t hitung sebesar -0,119, sedangkan $t$ tabel sebesar 2,0057, sehingga dari hasil yang didapatkan $\mathrm{t}$ hitung $<\mathrm{t}$ tabel, dengan tingkat signifikansi sebesar 0,905 yang berada diatas 0,05 berarti hipotesis Ho diterima, bahwa variabel kompensasi tidak berpengaruh secara parsial terhadap kinerja karyawan. Hal ini sejalan dengan penelitian yang telah dilakukan oleh Joko Purnomo yang menyatakan bahwa kompensasi tidak berpengaruh secara parsial terhadap kinerja.

4.2.4 Analisis Pengaruh Kepemimpinan, Kompensasi, dan Motivasi terhadap Kinerja Karyawan

Berdasarkan hipotesis peneliti:

Ho4: Kepemimpinan, kompensasi dan motivasi tidak berpengaruh secara simultan terhadap kinerja karyawan

Ha4: Kepemimpinan, kompensasi dan motivasi berpengaruh secara simultan terhadap kinerja karyawan

Dari hasil penelitian, diperoleh $\mathrm{f}$ hitung sebesar 224,442, sedangkan $\mathrm{f}$ tabel sebesar 2,78, sehingga dari hasil yang didapatkan $\mathrm{f}$ hitung $>\mathrm{f}$ tabel, dengan tingkat signifikansi sebesar 0,00 yang berada dibawah 0,05 berarti hipotesis Ha diterima, bahwa variabel kepemimpinan, kompensasi dan motivasi secara simultan berpengaruh terhadap kinerja karyawan. Hal ini sejalan dengan penelitian yang telah dilakukan oleh Anggara Nasution yang menyatakan bahwa kepemimpinan, remunerasi dan motivasi berpengaruh secara simultan terhadap kinerja.

\section{Kesimpulan dan Saran}

\subsection{Kesimpulan}

Berdasarkan hasil analisis data serta pembahasan yang sudah diuraikan di atas, maka kesimpulan yang dapat diambil dari penelitian tentang pengaruh kepemimpinan, kompensasi dan motivasi terhadap kinerja karyawan adalah sebagai berikut: 
1. Kepemimpinan berpengaruh secara parsial terhadap kinerja karyawan

2. Kompensasi tidak berpengaruh secara parsial terhadap kinerja karyawan

3. Motivasi tidak berpengaruh secara parsial terhadap kinerja karyawan

4. Kepemimpinan, kompensasi, dan motivasi secara simultan berpengaruh terhadap kinerja karyawan.

\subsection{Implikasi Manajerial}

Hasil penelitian menunjukkan bahwa secara bersama-sama seluruh variabel independen yaitu kepemimpinan, kompensasi dan motivasi berpengaruh terhadap kinerja karyawan. Dari ketiga variabel independen tersebut variabel kepemimpinan dominan berpengaruh dalam peningkatan kinerja karyawan. Hal ini berarti bahwa peranan seorang pemimpin dalam mengatur, mengawasi dan mengarahkan seluruh staff dan satuan yang ada dibawah kepemimpinannya sangatlah penting. Agar tercipta kinerja yang baik, seorang pemimpin perlu memberikan teladan yang positif, dapat membina dan melakukan pengawasan terhadap para bawahannya, serta dapat mengambil keputusan dengan cepat, tegas dan tidak pandang bulu guna meningkatkan kinerja karyawan.

\subsection{Saran}

Berdasarkan kesimpulan yang ada maka penulis dapat memberikan saran-saran sebagai berikut:

1. Bagi Perusahaan, kepemimpinan yang baik dapat meningkatkan kinerja karyawan. Untuk itu diperlukan sosok seorang pemimpin yang dapat memberikan teladan yang positif, yang dapat membina dan memberikan pengawasan yang baik kepada bawahannya, serta dapat mengambil keputusan yang cepat, tegas dan bijaksana demi tercapainya visi dan misi Perusahaan. Seorang pemimpin juga diharapkan dapat memengaruhi moral, motivasi, kepuasan kerja, kualitas kerja dan tingkat prestasi kerja para karyawan.

2. Penelitian ini hanya menggunakan variabel kepemimpinan, motivasi dan kompensasi dalam kaitannya dengan kinerja. Bagi peneliti selanjutnya dapat menambahkan beberapa variabel lain seperti kedisiplinan, kompetensi, lingkungan kerja, prestasi kerja dan lain sebagainya sebagai penunjang kinerja.

\section{Referensi}

Adipati, K. (2018). PENGARUH KOMPENSASI TERHADAP MOTIVASI KINERJA KARYAWAN PADA PT. MNCLEASING PALEMBANG. Jurnal Ilmiah Ekonomi Global Masa Kini, 8(2), 74-78.

Al Rasyid, F., Roswaty, R., \& Kurniawan, M. (2018). PENGARUH GAYA KEPEMIMPINAN TERHADAP KEPUASAN KERJA KARYAWAN PADAPT. CIOMAS ADISATWAPALEMBANG. Jurnal Ilmiah Ekonomi Global Masa Kini, 8(2), 90-94.

Amha, G. G., \& Brhane, F. (2020). Determinant of Employee Performance in Public Organization: The Case of Dessie City Municipality Office. International Journal of Marketing \& Human Resource Research,1(01), 1-13. Retrieved from http://journal.jisinstitute.org/index.php/ijmhrr/article/view/71

Anoraga. (2009). Sistem Kompensasi. Jakarta: Rineka Cipta. 
Anwar, Y. (2018). Pengaruh kompensasi dan motivasi terhadap prestasi kerja karyawan PT. Cipta prima kontrindo Palembang-sumatera selatan. Jurnal Ilmiah Ekonomi Global Masa Kini, 8(3), 31-36.

Bari, M. S., \& Al-Din, M. Z. H. M. (2020). Research on Strategic Human Resource Management Innovation-Oriented. International Journal of Marketing \& Human Resource Research, 1(01), 14-23. Retrieved from http://journal.jisinstitute.org/index.php/ijmhrr/article/view/45

Dajan, A. (2000). Pengantar Metode Statistik (2 ed.). Jakarta: LP3ES.

DP, M. K. (2020). Pengaruh Gaya Kepemimpinan terhadap Kinerja pada Bidang Pemberantasan Badan Narkotika Nasional Provinsi Sumatera Selatan. Jurnal Ilmiah Ekonomi Global Masa Kini, 11(1), 16-21.

Erwinsyah, E. (2016). PENGARUH KOMPENSASI TERHADAP MOTIVASI KERJA KARYAWAN PDAM TIRTA MUSI PALEMBANG. Jurnal Ilmiah Ekonomi Global Masa Kini, 6(1), 13-17.

Ghozali, I. (2004). Model Persamaan Struktural, Konsep dan Aplikasi dengan Program AMOS. Semarang: Undip.

Gibson, J. L., Ivancevich, J. M., \& Donelly, J. (2004). Organisasi dan Manajemen, Perilaku, Struktur, Proses. (D. Wahid, Penyunt.) Jakarta: Erlangga.

Handayani, S., \& Firmansyah, A. (2016). Analisa Manajerial Sistem Terhadap Produktifitas Karyawan. Jurnal Ilmiah ekonomi global masa kini, 7(2), 30-36.

Handayani, S. (2018). Pengaruh Kompensasi Finansial Terhadap Kinerja Pegawai Harian Lepas di Dinas Lingkungan Hidup dan Kebersihan Kota Palembang. Jurnal Ilmiah Ekonomi Global Masa Kini, 8(1), 12-20.

Hasibuan. (2011). Manajemen Sumber Daya Manusia Dasar dan Kunci Keberhasilan. Jakarta: Gunung Agung.

Heryati, A. (2018). Hubungan Antara Pendidikan dan Pelatihan (Diklat) K3 dan Pemberian kompensasi Terhadap Kinerja Karyawan PT. Kereta Api Indonesia (Persero) Devisi Regional III Palembang. Jurnal Ilmiah Ekonomi Global Masa Kini, 9(1), 71-76.

J., C. K. M. (2020). Employees Work Motivation and Its Effect on their Performance. International Journal of Community Service \& Engagement, 1(01), 39-43. Retrieved from http://journal.jis-institute.org/index.php/ijcse/article/view/72

J, G., \& Baron, R. A. (2000). Perilaku Organisasi. (H. Pujatmaka, Penyunt.) Jakarta: Prentice Hall.

Jogiyanto. (2011). Konsep dan Aplikasi Structural Equation Modelling Berbasis Varian Dalam Penelitian Bisnis. Yogyakarta: YKPN.

Liana, W. (2020). Pengaruh Motivasi terhadap Produktivitas Karyawan PT Telkom Indonesia, Tbk Cabang Palembang. Jurnal Nasional Manajemen Pemasaran \& SDM, 1(01), 65-72. https://doi.org/10.47747/jnmpsdm.v1i01.25

Munandar, \& Sunyoto, A. (2004). Psikologi Industri dan Organisasi. Jakarta: Universitas Indonesia. 
Robbins. (2000). Organizational Behaviour (9TH ed.). New Jersey: Prentice Hall.

Robbins. (2008). The Truth About Managing People (Second Edition ed.). Upper Sadle River, New Jersey: Pearson Education Inc.

Robbins, S. P. (2001). Perilaku Organisasi. (D. Angelina, Penyunt.) Jakarta: Prenhallindo.

Sari, Y. K. (2020). Pengaruh Motivasi terhadap Semangat Kerja Pegawai pada Kantor Balai Diklat Keuangan Palembang. Jurnal Nasional Manajemen Pemasaran \& SDM, 1(01), 54-64. https://doi.org/10.47747/jnmpsdm.v1i01.8

Septiadi, M. D., Marnisah, L., \& Handayani, S. (2020). Pengaruh Motivasi terhadap Kinerja Karyawan PT Brawijaya Utama Palembang. Jurnal Nasional Manajemen Pemasaran \& SDM, 1(01), 38-44. https://doi.org/10.47747/jnmpsdm.v1i01.5

Seto, A. A. (2018). Kompensasi, Motivasi dan Kompetensi Terhadap Minat Melakukan Penelitian pada Dosen di Universitas Tridinanti Palembang. Jurnal Ilmiah Ekonomi Global Masa Kini, 9(2), 103-110.

Siagian, S. P. (2003). Pengembangan Sumber Daya Insani. Jakarta: Gunung Agung.

Siregar, M. I., \& Hamdani, M. (2018). Pengaruh Kesesuaian Kompensasi, Keefektifan Sistem Pengendalian Internal, Budaya Organisasi, Dan Kompetensi Terhadap Fraud (Studi pada Satuan Kerja Vertikal Kementerian Keuangan Provinsi Lampung). Jurnal Ilmiah Ekonomi Global Masa Kini, 9(1), 30-37.

Sugiyono. (2003). Statistik Untuk Penelitian. Bandung: Alfabeta.

Sugiyono. (2010). Metode Penelitian Kuantitatif, Kualitatif dan R\&D. Bandung: Alfabeta.

Suyadi, S. (2016). ANALISIS HUBUNGAN KEPEMIMPINAN MELAYANI DENGAN KOMITMEN ORGANISASIONAL: STUDI PADA BPJS KESEHATAN KANTOR WILAYAH JAMBI. Jurnal Ilmiah Ekonomi Global Masa Kini, 7(2), 37-43.

Tika, P. (2006). Budaya Organisasi dan Peningkatan Kinerja Perusahaan. Jakarta: PT. Bumi Aksara.

Triani, F., Halin, H., \& Wadud, M. (2020). Effect of Organizational Citizenship Behavior on Employee Performance at PT Surya Dermato Medica Palembang. International Journal of Community Service \& Engagement,1(01), 11-18. Retrieved from http://journal.jisinstitute.org/index.php/ijcse/article/view/75

Veithzal, R. (2010). Manajemen Sumber Daya Manusia. Jakarta: PT. Raja Grafindo Persada.

Veithzal, R., \& Mulyadi, D. (2010). Kepemimpinan dan Perilaku Organisasi. Jakarta: Rajawali Press.

Winardi, J. (2002). Manajemen Konflik dan MSDM. Jakarta: Gramedia.

Yuki, G. (2010). Leadership in Organization (Seventeenth ed.). Upper Sadle River, New Jersey: Pears. 